\title{
Prevalence and risk factors of postpartum depression at a tertiary care institute
}

\author{
Vanithamani Sivapragasam $^{1 *}$, Anitha A. Manjappa ${ }^{1}$, Aruna B. Patil ${ }^{2}$, Monicka Kalaimani ${ }^{3}$
}

\author{
${ }^{1}$ Department of Obstetrics and Gynecology, ESICMC PGIMSR, Chennai, Tamil Nadu, India \\ ${ }^{2}$ Department of Community Medicine, ESICMC PGIMSR, Chennai, Tamil Nadu, India \\ ${ }^{3}$ Departments of Psychiatry, ESICMC PGIMSR, Chennai, Tamil Nadu, India
}

Received: 03 May 2019

Accepted: 05 June 2019

\author{
*Correspondence: \\ Dr. Vanithamani Sivapragasam, \\ E-mail: vanithashivashankar@gmail.com
}

Copyright: () the author(s), publisher and licensee Medip Academy. This is an open-access article distributed under the terms of the Creative Commons Attribution Non-Commercial License, which permits unrestricted non-commercial use, distribution, and reproduction in any medium, provided the original work is properly cited.

\begin{abstract}
Background: Up to $85 \%$ of the women experience some type of mood disturbance in the postnatal period. Postpartum depression affects bonding with infant which may lead to malnutrition and other complications in the infant. This article focuses on the prevalence of depression among postnatal women attending a tertiary care institute in Chennai and to identify the risk factors that affect postpartum depression.

Methods: This study was a cross sectional study, performed over a period of three months from January 2019 to March 2019. 200 postnatal mothers were recruited for the study, who were in postpartum period from 1 to 6 weeks after delivery. Specially designed proforma was used to record various determinants to assess the risk factors which could contribute to postpartum depression. The Edinburgh Postnatal Depression Scale was used to detect the depressive symptoms in postnatal mother.

Results: A total of 200 cases were studied. Prevalence of postpartum depression was found to be $25 \%$. Primi gravida, history of miscarriage and unplanned pregnancy were associated with increased risk of developing depression in the postnatal period. Fear regarding gender of the child and failure of lactation were not contributing risk factors to postpartum depression. Spacious house and partner support were found to be protective factors to combat depression in postnatal women.

Conclusions: Prevalence of postpartum depression was 25\%. Significant association was found between primi gravida, history of miscarriage, unplanned pregnancy and postpartum depression. Early screening of the women will reduce the adverse outcomes among both mother and the child.
\end{abstract}

Keywords: Depression, Postnatal, Prevalence, Risk factors

\section{INTRODUCTION}

Pregnancy and postnatal period are considered as most fragile periods for women in her life. Postpartum period is a time of tremendous emotional and physical change for women as they adapt to new roles and alteration in their physiology. Biological, psychological and social factors operate in a combined way, resulting in various mental health problems occurring at this stage. In addition to physical stress, significant psycho social stress is experienced by the mother. Hence women are vulnerable to mood disorders in this period. Up to $85 \%$ of the women experience some type of mood disturbance in postnatal period. ${ }^{1}$ Postpartum psychiatric disorders can be divided in to three categories depending on the severity: Postpartum blues, Postpartum depression and Postpartum psychosis. Postpartum blues is usually mild and transient, resolves in few days to a week. 
Postpartum depression (PPD) is a depressive disorder, which affects women after childbirth. Despite its serious consequences and amenability to treatment, PPD often remains unrecognized. Depression during this time of life affects bonding with infant which may lead to malnutrition and other various complications in the infant. Infant might be neglected in its early growing phase in life, which may lead to psychiatric illness later. Women affected with PPD are also at high risk for recurrent depression. Many mothers are not aware that they are depressed; others have social stigma which prevents them from seeking medical help. If the depression is undetected or detected but not taking treatment due to lack of awareness of the disease, it has serious consequences for mother, child and the whole family. The prevalence of PPD is $10 \%-15 \%$ in developed countries while most of the Indian and South Asian studies show prevalence of $15 \% .^{2}$ The first and most important step to manage postpartum depression is accurate assessment of the symptoms and early diagnosis. Screening helps in identifying mothers at risk and assists in prevention of PPD. This study focuses on the prevalence of probable depression among postnatal women attending a tertiary care institute in south India and to identify the risk factors that affect postpartum depression. This study intends to add to the existing knowledge about the prevalence of postpartum depression and associated risk factors.

\section{METHODS}

This study was a cross sectional study, performed over a period of three months from January 2019 to march 2019 at ESIC Medical College and PGIMSR, Chennai, Tamil Nadu, a teaching hospital in southern India. 200 postnatal mothers were recruited for the study, who were in postpartum period from 1 to 6 weeks after delivery. They were recruited from in patients and postnatal clinic after applying inclusion and exclusion criteria. After explaining the nature and purpose of the study, written informed consent was taken from the participants.

Specially designed proforma was used to record various determinants to assess the risk factors which could contribute to postpartum depression. Then pre-designed and pretested questionnaire (EDPS- Edinburgh Postnatal Depression Scale) was used to detect the depressive symptoms in postnatal mothers. EDPS was created specifically for postpartum women for screening depression. It has been well validated and found to have high sensitivity, specificity and accuracy. EDPS scale has ten components in it. Each item is rated from 0 to 3, yielding a total score of 0-30. Seven of its items are reverse scored. EDPS score cut off 13 or more was used to calculate the prevalence of postnatal depression in the study group.

The scale was administered by the investigator in the language known to the patient for ease of understanding, which was Tamil.

\section{Inclusion criteria}

- All postnatal mothers from day 8 to 6 weeks postpartum irrespective of age, parity, socio economic status, mode of delivery and gestational age at delivery.

\section{Exclusion criteria}

- Previously diagnosed to have depression

- Women on treatment for any psychiatric disorder.

\section{The various determinants that were evaluated to assess the risk factors}

- Social and demographic factors: age, educational qualification, socio economic status, whether working or not.

- Medical and obstetric history: presence of any comorbid illness, gravida (primi/ multi), history of treatment for infertility, history of miscarriage, history of intra uterine fetal demise (IUFD), number of living children, gender of living children, whether pregnancy was planned pregnancy/ unplanned pregnancy, presence of complication during pregnancy.

- Perinatal events: mode of delivery, gestational age at delivery, complication during delivery, fear regarding gender of the child, gender of the baby, NICU admission, Lactation failure.

- Family and relationship factors: whether single parent, family structure (nuclear/joint), housing (spacious/overcrowding), financial difficulty, support from partner, support from parent, support from in laws.

\section{Statistical analysis}

The results for qualitative data were presented in frequency and percentage. Binary logistic regression was used to predict the contribution of each independent risk factor to arrive at the depression level, which happens to be the dependent risk factor in this study. The statistical analysis was done by using SPSS 21.0. The significant level was used at $\mathrm{p}<0.05$. The following symbols were used. * just significant at $\mathrm{p}<0.05^{* *}$ more significant at $\mathrm{p}<0.001, * * *$ highly significant at $\mathrm{p}<0.0001$ and NS for Not significant.

\section{RESULTS}

Table 1: Prevalence of postpartum depression.

\begin{tabular}{|ll|}
\hline $\begin{array}{l}\text { Postpartum } \\
\text { depression }\end{array}$ & $\begin{array}{l}\text { Number of individuals and } \\
\text { (percentage) }\end{array}$ \\
\hline Present & $51(25 \%)$ \\
\hline Absent & $149(75 \%)$ \\
\hline
\end{tabular}


A total of 200 cases were studied. Prevalence of postnatal depression was found to be $25 \%$ using Edinburgh Postnatal Depression Scale. The score $\geq 13$ was considered as presence of depression (Table 1).

Most common age group in the study was 21 years to 30 years $(77 \%)$ followed by 31 years to 40 years $(22 \%)$. Out of 200 women $61 \%$ of the women were not working, while $39 \%$ were working women. A total of 116 women $(58 \%)$ were graduates, out of which 94 women had undergraduate degree while 22 women had postgraduate degree. Women belonging to upper class were common $48 \%$, followed by middle class $24 \%$ (Table 2 ).

Table 2: Socio demographic characteristics of study group.

\begin{tabular}{|c|c|c|c|c|}
\hline Demographic data & & Number of women & Percentage & $P$ value \\
\hline & $\leq 20$ & 2 & $1 \%$ & 0.139 \\
\hline & $21-30$ & 154 & $77 \%$ & \\
\hline Age & $31-40$ & 43 & $22 \%$ & \\
\hline & 41 and above & 1 & $1 \%$ & \\
\hline & Yes & 78 & $39 \%$ & 0.483 \\
\hline Working & No & 121 & $61 \%$ & \\
\hline & Pre-primary & 2 & $1 \%$ & 0.612 \\
\hline & I-VIII & 19 & $9 \%$ & \\
\hline Educational qualification & IX-XII & 63 & $32 \%$ & \\
\hline & Undergraduate & 94 & $47 \%$ & \\
\hline & Postgraduate & 22 & $11 \%$ & \\
\hline & Upper & 96 & $48 \%$ & 0.629 \\
\hline Socio economic class & Upper middle & 40 & $20 \%$ & \\
\hline 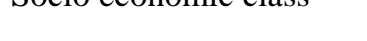 & Middle & 49 & $24 \%$ & \\
\hline & Lower middle & 15 & $8 \%$ & \\
\hline
\end{tabular}

$\dagger$ Using Chi square test

Table 3: Obstetric factors and risk of postnatal depression.

\begin{tabular}{|c|c|c|c|c|c|c|}
\hline \multirow[b]{2}{*}{ Risk factor } & & \multicolumn{4}{|c|}{ Depression } & \multirow{2}{*}{$p$ value } \\
\hline & & Absent & Percentage & Present & Percentage & \\
\hline \multirow{2}{*}{ Treatment for infertility } & No & 139 & $93 \%$ & 48 & $94 \%$ & 0.836 \\
\hline & Yes & 10 & $7 \%$ & 3 & $6 \%$ & \\
\hline \multirow{2}{*}{ Gravida } & Primi & 72 & $48 \%$ & 16 & $31 \%$ & $0.035^{*}$ \\
\hline & Multi & 77 & $52 \%$ & 35 & $69 \%$ & \\
\hline \multirow{3}{*}{ Number of living children } & $\begin{array}{l}\text { No living } \\
\text { issue }\end{array}$ & 82 & $55 \%$ & 20 & $39 \%$ & 0.148 \\
\hline & One & 61 & $41 \%$ & 28 & $55 \%$ & \\
\hline & Two & 6 & $4 \%$ & 3 & $6 \%$ & \\
\hline \multirow{3}{*}{ Gender of living children } & Boy & 36 & $24 \%$ & 17 & $33 \%$ & 0.570 \\
\hline & Girl & 32 & $21 \%$ & 13 & $26 \%$ & \\
\hline & Both & 3 & $2 \%$ & 1 & $2 \%$ & \\
\hline \multirow{2}{*}{ History of miscarriage } & Absent & 120 & $80 \%$ & 40 & $78 \%$ & 0.827 \\
\hline & Present & 29 & $20 \%$ & 11 & $22 \%$ & \\
\hline \multirow{2}{*}{ History of IUFD } & Absent & 144 & $97 \%$ & 49 & $96 \%$ & 0.849 \\
\hline & Present & 5 & $3 \%$ & 2 & $4 \%$ & \\
\hline \multirow{2}{*}{ Co morbid illness } & Absent & 132 & $89 \%$ & 44 & $86 \%$ & 0.660 \\
\hline & Present & 17 & $11 \%$ & 7 & $14 \%$ & \\
\hline \multirow{2}{*}{ Present pregnancy } & Planned & 131 & $88 \%$ & 46 & $90 \%$ & 0.660 \\
\hline & Unplanned & 18 & $12 \%$ & 5 & $10 \%$ & \\
\hline \multirow{2}{*}{ Complication during pregnancy } & Absent & 74 & $50 \%$ & 20 & $39 \%$ & 0.073 \\
\hline & Present & 75 & $50 \%$ & 31 & $61 \%$ & \\
\hline
\end{tabular}

$\dagger$ Using Chi square test 
Out of 200 women, $44 \%$ were primi gravida, while $56 \%$ were multi gravida. $7 \%$ of the women had history of infertility. $20 \%$ of the women had history of miscarriage. $4 \%$ of the women had history of intra uterine fetal demise. $50 \%$ of the women had no living children. $45 \%$ of the women had one living child. $5 \%$ of the women had two living children. $27 \%$ of the women had living boy child. $23 \%$ of the women had living girl child. Co-morbid illness was present in $12 \%$ of the cases.

Present pregnancy was planned pregnancy in $88 \%$ of the cases and unplanned in $12 \%$ of the cases. Either medical or obstetric complication was present in $53 \%$ of the cases (Table 3).

Table 4: Perinatal events and risk of postpartum depression.

\begin{tabular}{|c|c|c|c|c|c|c|}
\hline \multicolumn{2}{|l|}{ Risk factor } & \multicolumn{4}{|c|}{ Depression } & \multirow{2}{*}{ p value $\dagger$} \\
\hline \multirow{4}{*}{ Mode of delivery } & & Absent & Percentage & Present & Percentage & \\
\hline & Vaginal & 54 & $36 \%$ & 12 & $24 \%$ & 0.155 \\
\hline & Instrumental & 2 & $1 \%$ & 2 & $4 \%$ & \\
\hline & Caesarean section & 93 & $63 \%$ & 37 & $72 \%$ & \\
\hline \multirow{2}{*}{$\begin{array}{l}\text { Gestational age at } \\
\text { delivery }\end{array}$} & Term & 141 & $95 \%$ & 49 & $96 \%$ & 0.682 \\
\hline & Preterm & 8 & $5 \%$ & 2 & $4 \%$ & \\
\hline \multirow{2}{*}{$\begin{array}{l}\text { Complication during } \\
\text { delivery }\end{array}$} & Absent & 147 & $99 \%$ & 48 & $94 \%$ & 0.073 \\
\hline & Present & 2 & $1 \%$ & 3 & $6 \%$ & \\
\hline \multirow{2}{*}{$\begin{array}{l}\text { Fear regarding gender } \\
\text { of child }\end{array}$} & Absent & 130 & $87 \%$ & 38 & $75 \%$ & $0.032 *$ \\
\hline & Present & 19 & $13 \%$ & 13 & $25 \%$ & \\
\hline \multirow{3}{*}{ Gender of baby } & Boy & 70 & $47 \%$ & 22 & $43 \%$ & 0.607 \\
\hline & Girl & 77 & $52 \%$ & 29 & $57 \%$ & \\
\hline & Both & 2 & $1 \%$ & 0 & $0 \%$ & \\
\hline \multirow{2}{*}{ NICU admission } & Absent & 125 & $84 \%$ & 41 & $80 \%$ & 0.566 \\
\hline & Present & 24 & $16 \%$ & 10 & $20 \%$ & \\
\hline \multirow{2}{*}{ Lactation failure } & Absent & 133 & $89 \%$ & 38 & $75 \%$ & $0.010^{*}$ \\
\hline & Present & 16 & $11 \%$ & 13 & $25 \%$ & \\
\hline
\end{tabular}

$\dagger$ Using Chi square test

Table 5: Family and relationship factors and risk of postpartum depression.

\begin{tabular}{|c|c|c|c|c|c|c|}
\hline \multirow[t]{2}{*}{ Risk factor } & & \multicolumn{4}{|c|}{ Depression } & \multirow{2}{*}{ p value $\uparrow$} \\
\hline & & Absent & Percentage & Present & Percentage & \\
\hline \multirow{2}{*}{ Single parent } & No & 130 & $87 \%$ & 40 & $78 \%$ & 0.128 \\
\hline & Yes & 19 & $13 \%$ & 11 & $22 \%$ & \\
\hline \multirow{2}{*}{ Family structure } & Nuclear & 82 & $55 \%$ & 28 & $55 \%$ & 0.987 \\
\hline & Joint & 67 & $45 \%$ & 23 & $45 \%$ & \\
\hline \multirow{2}{*}{ Housing } & Spacious & 129 & $87 \%$ & 30 & $59 \%$ & $0.0001 * * *$ \\
\hline & Overcrowded & 20 & $13 \%$ & 21 & $41 \%$ & \\
\hline \multirow{2}{*}{ Financial difficulty } & Absent & 120 & $80 \%$ & 33 & $65 \%$ & $0.021 *$ \\
\hline & Present & 29 & $20 \%$ & 18 & $35 \%$ & \\
\hline \multirow{2}{*}{ Support from partner } & Present & 148 & $99 \%$ & 49 & $96 \%$ & 0.10 \\
\hline & Absent & 1 & $1 \%$ & 2 & $4 \%$ & \\
\hline \multirow{2}{*}{ Support from parent } & Present & 138 & $93 \%$ & 44 & $86 \%$ & 0.172 \\
\hline & Absent & 11 & $7 \%$ & 7 & $14 \%$ & \\
\hline \multirow{2}{*}{ Support from in laws } & Present & 119 & $80 \%$ & 36 & $71 \%$ & 0.171 \\
\hline & Absent & 30 & $20 \%$ & 15 & $29 \%$ & \\
\hline
\end{tabular}

$\dagger$ Using Chi square test

Out of 200 women $65 \%$ women underwent cesarean section, $33 \%$ women had vaginal delivery. Ninety five percent women delivered at term, while 5\% women delivered at preterm. Complication during delivery was present in 5 cases. Fear regarding gender of the child was present in $16 \%$ of the cases. NICU admission was present in $17 \%$ of the cases. Lactation failure was present in $15 \%$ of the cases (Table 4). Out of the 200 women, $15 \%$ of the women were single parent. $55 \%$ of the women had nuclear family. $45 \%$ of the women had joint family. $80 \%$ 
of the women had spacious house. $20 \%$ of the women had overcrowded house. Financial difficulty was present for $24 \%$ of the women. Almost all women had partner support (98\%). Parent support was absent in $9 \%$ of the cases. In laws support was absent in $23 \%$ of the cases (Table 5).

Table 6: Binary logistic regression by using Backward LR Method (Variables in the equation step 1).

\begin{tabular}{|c|c|c|c|c|c|c|c|c|}
\hline \multirow{2}{*}{ Risk factors } & \multirow{2}{*}{$\begin{array}{l}\text { B } \\
\text { coefficient }\end{array}$} & \multirow{2}{*}{ S.E. } & \multirow{2}{*}{$\begin{array}{l}\text { Wald } \\
\text { statistics }\end{array}$} & \multirow{2}{*}{ df } & \multirow{2}{*}{$\begin{array}{l}\mathrm{p} \\
\text { value }\end{array}$} & \multirow{2}{*}{$\begin{array}{l}\mathrm{OR}= \\
\operatorname{Exp}(\mathbf{B})\end{array}$} & \multicolumn{2}{|c|}{ 95\% C.I. for $\operatorname{EXP(B)}$} \\
\hline & & & & & & & Lower & Upper \\
\hline Age $(\leq 30)$ & 0.397 & 0.513 & 0.597 & 1 & 0.44 & 1.487 & 0.543 & 4.067 \\
\hline Working (yes) & -0.342 & 0.445 & 0.59 & 1 & 0.442 & 0.71 & 0.297 & 1.7 \\
\hline Education & & & 6.535 & 2 & 0.038 & & & \\
\hline Education (primary) & 1.725 & 0.931 & 3.432 & 1 & 0.064 & 5.615 & 0.905 & 34.846 \\
\hline Education (secondary) & -0.603 & 0.463 & 1.697 & 1 & 0.193 & 0.547 & 0.221 & 1.355 \\
\hline Socio economic class & & & 1.154 & 3 & 0.764 & & & \\
\hline Upper class & 0.349 & 0.802 & 0.19 & 1 & 0.663 & 1.418 & 0.295 & 6.826 \\
\hline Middle class & -0.14 & 0.909 & 0.024 & 1 & 0.877 & 0.869 & 0.146 & 5.163 \\
\hline Lower class & -0.115 & 0.838 & 0.019 & 1 & 0.89 & 0.891 & 0.172 & 4.607 \\
\hline Single parent & -0.243 & 0.612 & 0.158 & 1 & 0.691 & 0.784 & 0.237 & 2.601 \\
\hline History of infertility & 0.865 & 0.989 & 0.766 & 1 & 0.382 & 2.375 & 0.342 & 16.496 \\
\hline Primi gravida & 2.218 & 1.104 & 4.038 & 1 & 0.044 & 9.193 & 1.056 & 80.009 \\
\hline Number of living children & & & 1.983 & 2 & 0.371 & & & \\
\hline No living child & 0.768 & 1.34 & 0.329 & 1 & 0.566 & 2.156 & 0.156 & 29.793 \\
\hline One living child & 1.433 & 1.068 & 1.799 & 1 & 0.18 & 4.19 & 0.516 & 34.003 \\
\hline Having girl child & 0.366 & 0.596 & 0.376 & 1 & 0.54 & 1.442 & 0.448 & 4.641 \\
\hline History of miscarriage & 1.701 & 0.707 & 5.787 & 1 & 0.016 & 5.478 & 1.37 & 21.901 \\
\hline $\begin{array}{l}\text { History of Intra uterine } \\
\text { fetal demise }\end{array}$ & 0.017 & 1.049 & 0 & 1 & 0.987 & 1.017 & 0.13 & 7.943 \\
\hline Presence of comorbidity & 0.229 & 0.618 & 0.137 & 1 & 0.711 & 1.257 & 0.374 & 4.223 \\
\hline Unplanned pregnancy & 2.138 & 0.823 & 6.738 & 1 & 0.009 & 8.478 & 1.688 & 42.582 \\
\hline $\begin{array}{l}\text { Complication during } \\
\text { pregnancy }\end{array}$ & -0.256 & 0.457 & 0.315 & 1 & 0.575 & 0.774 & 0.316 & 1.895 \\
\hline Mode of delivery & & & 1.494 & 2 & 0.474 & & & \\
\hline Cesarean delivery & -0.388 & 0.461 & 0.709 & 1 & 0.4 & 0.678 & 0.275 & 1.674 \\
\hline Vaginal delivery & -1.7 & 1.644 & 1.069 & 1 & 0.301 & 0.183 & 0.007 & 4.583 \\
\hline Preterm delivery & -0.578 & 1.02 & 0.321 & 1 & 0.571 & 0.561 & 0.076 & 4.143 \\
\hline $\begin{array}{l}\text { Complication during } \\
\text { delivery }\end{array}$ & -1.241 & 1.138 & 1.19 & 1 & 0.275 & 0.289 & 0.031 & 2.69 \\
\hline $\begin{array}{l}\text { Fear regarding gender of } \\
\text { the child }\end{array}$ & -1.454 & 0.542 & 7.208 & 1 & 0.007 & 0.234 & 0.081 & 0.675 \\
\hline Gender of the baby & & & 0.047 & 2 & 0.977 & & & \\
\hline Girl baby & -20.418 & 28385.52 & 0 & 1 & 0.999 & 0 & 0 & . \\
\hline Boy baby & -20.323 & 28385.52 & 0 & 1 & 0.999 & 0 & 0 & \\
\hline NICU admission & -0.094 & 0.545 & 0.03 & 1 & 0.863 & 0.91 & 0.313 & 2.649 \\
\hline Lactation failure & -0.969 & 0.64 & 2.294 & 1 & 0.13 & 0.379 & 0.108 & 1.33 \\
\hline Nuclear family & -0.441 & 0.453 & 0.946 & 1 & 0.331 & 0.644 & 0.265 & 1.564 \\
\hline Overcrowded house & -2.082 & 0.62 & 11.269 & 1 & 0.001 & 0.125 & 0.037 & 0.42 \\
\hline Financial difficulty & -0.208 & 0.549 & 0.143 & 1 & 0.705 & 0.812 & 0.277 & 2.385 \\
\hline Partner support- absent & -3.235 & 1.915 & 2.853 & 1 & 0.091 & 0.039 & 0.001 & 1.68 \\
\hline Parent support- absent & -0.271 & 0.745 & 0.133 & 1 & 0.716 & 0.762 & 0.177 & 3.283 \\
\hline In laws support- absent & -0.167 & 0.521 & 0.102 & 1 & 0.749 & 0.846 & 0.305 & 2.35 \\
\hline Constant & 20.541 & 28385.52 & 0 & 1 & 0.999 & $8.33 \mathrm{E}+08$ & & \\
\hline
\end{tabular}


Each independent risk factor to postpartum depression was analyzed using Binary logistic regression by using Backward stepwise Likelihood Ratio method. In this method insignificant risk factors had been removed stepwise to give the most significant risk factors. In our study Backward LR method followed 20 steps to give the most significant risk factors. Table 6 shows all risk factors at the entry level (step1) using Backward LR method with $\mathrm{p}$ values of 0.05 for entry and 0.10 for removal of the variable from the model. The classification table of the model built was able to correctly classify the sample for depression $78.5 \%$ times. Depression was the dichotomous dependent variable and all risk factors entered in step 1 were independent variables (Table 6).

Table 7: Binary logistic regression by using Backward LR Method (Variables in the equation-Final step).

\begin{tabular}{|c|c|c|c|c|c|c|c|c|}
\hline \multirow{2}{*}{ Risk factors } & \multirow{2}{*}{ B coefficient } & \multirow{2}{*}{ S.E. } & \multirow{2}{*}{$\begin{array}{l}\text { Wald } \\
\text { statistics }\end{array}$} & \multirow{2}{*}{ df } & \multirow{2}{*}{ p value } & \multirow{2}{*}{$\begin{array}{l}\text { OR= Exp } \\
\text { (B) }\end{array}$} & \multicolumn{2}{|c|}{ 95\% C.I. for $\operatorname{EXP(B)}$} \\
\hline & & & & & & & Lower & Upper \\
\hline Education & & & 4.865 & 2 & 0.088 & & & \\
\hline Primary Education & 1.108 & 0.73 & 2.285 & 1 & 0.131 & 3.029 & 0.72 & $\begin{array}{l}12.74 \\
1\end{array}$ \\
\hline Secondary Education & -0.521 & 0.41 & 1.639 & 1 & 0.201 & 0.594 & 0.268 & 1.319 \\
\hline Primi gravida & 1.393 & 0.46 & 9.218 & 1 & $0.002 * *$ & 4.028 & 1.639 & 9.901 \\
\hline History of miscarriage & 1.275 & 0.54 & 5.61 & 1 & $0.018 *$ & 3.58 & 1.246 & $\begin{array}{l}10.28 \\
5\end{array}$ \\
\hline Unplanned pregnancy & 1.901 & 0.73 & 6.798 & 1 & $0.009 * *$ & 6.695 & 1.603 & $\begin{array}{l}27.95 \\
3\end{array}$ \\
\hline $\begin{array}{l}\text { Fear regarding gender } \\
\text { of the child }\end{array}$ & -1.36 & 0.48 & 8.13 & 1 & $0.004 * *$ & 0.257 & 0.101 & 0.654 \\
\hline Lactation failure & -1.092 & 0.51 & 4.554 & 1 & $0.033 *$ & 0.336 & 0.123 & 0.915 \\
\hline Overcrowded House & -2.165 & 0.49 & 19.68 & 1 & $0.0001 * * *$ & 0.115 & 0.044 & 0.299 \\
\hline Partner support- absent & -3.465 & 1.6 & 4.711 & 1 & $0.03 *$ & 0.031 & 0.001 & 0.715 \\
\hline Constant & 1.213 & 0.37 & 10.643 & 1 & 0.001 & 3.362 & & \\
\hline
\end{tabular}

$*$ Significant at $\mathrm{p}<0.05, * *$ very significant at $\mathrm{p}<0.001, * * *$ Highly significant at $\mathrm{p}<0.0001$

The final step of logistic regression was shown in the table 7 which describes the most significant risk factors to develop postnatal depression.

Educational qualification was not found as contributing risk factor to postpartum depression. Women with lesser educational qualification (primary education) were at 3 times $(\mathrm{OR}=3.029)$ increased risk of developing depression as compared to women with secondary and degree education, though it was statistically not significant (Table 7).

Primi gravida were at 4 times increased risk of postpartum depression compared to multi gravida $(\mathrm{OR}=4.028)$. Women with history of miscarriage were at 3 times increased risk of developing postpartum depression $(\mathrm{OR}=3.58)$. Women whose pregnancy was unplanned were at 6 times increased risk of developing postpartum depression (Table 7).

Fear regarding gender of the child $(\mathrm{OR}=0.257)$, failure of lactation $(\mathrm{OR}=0.336)$ were not contributing risk factors to postpartum depression in this study (Table 7).

Overcrowding of the house and absent partner support were found to have odds ratio of $\mathrm{OR}=0.115$ and $\mathrm{OR}=$
0.031 respectively as compared to spacious house and partner support. Hence spacious house and partner support were found to be protective factors to combat depression in postnatal women in this study (Table 7).

\section{DISCUSSION}

A total of 200 cases were studied. Prevalence of postpartum depression in the present study was found to be $25 \%$. Prevalence of $20.4 \%$ was found in a study conducted in western India by Modi VP et al. ${ }^{2}$ A study conducted in rural area of south India by Chandran $\mathrm{M}$ et al, showed prevalence of $19.8 \% .^{3}$ Another study by Saldanha D et al conducted in a military hospital, in north India showed prevalence of $21.5 \% .^{4} 38$ studies from India were included in systematic review and meta analysis done by Upadhyay RP et al. ${ }^{5}$ They included data from 20,043 mothers. The pooled prevalence of postpartum depression in India, in this meta-analysis was $22 \%$. Similar study conducted at tertiary care hospital in Andhra Pradesh by Bhuvana LG et al showed prevalence about $31.4 \% .^{6}$ Prevalence in our study was comparable to these studies.

Most common age group in the study was 21 years to 30 years $(77 \%)$ followed by 31 years to 40 years $(22 \%)$ 
which may be due to early age at marriage in our community. This was comparable to other studies done by Modi VP et al, Bhuvana LG et al, Kruthika K et al., ${ }^{2,6,7}$

Out of 200 women $61 \%$ of the women were not working, while $39 \%$ were working women. Similar finding was noted in a study conducted in south India by Kruthika $\mathrm{K}$ et al where majority of the mothers were housewives. ${ }^{7}$

A total of 116 women (58\%) were graduates, out of which 94 women had undergraduate degree while 22 women had postgraduate degree. Women belonging to upper class were common $48 \%$, followed by middle class $24 \%$.

Risk factors were analyzed using Binary logistic regression by using Backward LR Method. Analysis showed unplanned pregnancy, primi gravida and history of miscarriage were statistically significant for postpartum depression, hence they were potential risk factors.

Women whose pregnancy was unplanned were at 6 times increased risk of developing depression. Similar finding was observed in a study conducted by Modi VP et al. ${ }^{2}$

Primi gravida were at 4 times increased risk of developing postpartum depression compared to multi gravid $(\mathrm{OR}=4.028)$. A study conducted by Kruthika $\mathrm{K}$ et al showed prevalence of depression was high among primi gravida compared to multigravida. ${ }^{7}$ Another study conducted by Suguna A et al in rural maternity hospital in south India also showed primi gravida were at high risk of developing postnatal depression. ${ }^{8}$

Women with history of miscarriage were at 3 times increased risk of developing depression ( $\mathrm{OR}=3.58)$. A study conducted in north India by Nimisha DD et al showed that if there is any previous history of miscarriage, the odds that such a female gets depressed is 4.613 times higher than a female without any miscarriage. ${ }^{9}$

Educational qualification was not found as contributing risk factor to postpartum depression in our study. A study conducted by Suguna A et al also showed that there was no significant association between postnatal depression and age of the woman, educational status, occupation. ${ }^{8}$

Fear regarding gender of the child $(\mathrm{OR}=0.257)$, failure of lactation $(\mathrm{OR}=0.336)$ were significantly not contributing risk factors to postpartum depression in this study.

Partner support was found to be a protective factor to combat depression in postnatal women in this study. In a study conducted by Saldanha D et al in north India, the prevalence of postpartum depression was more $(60 \%)$ when partner support was not there. ${ }^{4}$
Study by Nimisha DD et al in north India showed that women who could not confide in their partners were observed to be having odds 10.43 times higher of having postpartum depression than those who could confide in their partners. ${ }^{9}$ Lack of partner support was associated with depression among postnatal women, in a study conducted by Swapan G et al in north india. ${ }^{10}$

Spacious house was found to have a protective role from developing postpartum depression in our study. Study by Swapan $G$ et al in north India also found similar finding that overcrowding of the house was significantly associated with postpartum depression. ${ }^{10}$

\section{CONCLUSION}

In our study, the prevalence of postpartum depression was $25 \%$. Prevalence in this hospital based study is consistent with the rates found in other studies. Important risk factors for postpartum depression found in this study were unplanned pregnancy, primi gravida and history of miscarriage. No significant association was noted between postpartum depression and age, educational qualification, socio economic status. Fear regarding gender of the child and failure of lactation were not contributing risk factors to postpartum depression in this study. Spacious house and partner support were found to be protective factors to combat depression in postnatal women in our study.

Early screening of postnatal women for depression will reduce the adverse outcomes among both mother and the child. But scarcity of available mental health resources, inequities in their distribution and inefficiencies in their utilization are the key obstacles to optimal mental health, especially in low resource countries.

Prevalence rate and risk factors in the present study strengthens the findings of previous studies and signifies the importance of identifying postpartum depression. Hence, we recommend screening of all postnatal mothers for depression during postpartum period based on this study. More extensive studies involving larger samples in future might be helpful in identifying additional risk factors for postpartum depression.

Funding: No funding sources Conflict of interest: None declared

Ethical approval: The study was approved by the Institutional Ethics Committee

\section{REFERENCES}

1. Nigam A, Prakash A, Maheshwari N. Postpartum depression in an Indian community: more prevalent less addressed issue. Int $\mathbf{J}$ Reprod Contracept Obstet Gynecol. 2016;5:2691-5.

2. Modi VP, Parikh MN, Valipay SK. A study on prevalence of postpartum depression and correlation 
with risk factors. Ann Indian Psychiatry. 2018;2:2732.

3. Chandran M, Tharyan P, Muliyil J, Abraham S. Postpartum depression in a cohort of women from a rural area of Tamil Nadu, India. British $\mathrm{J}$ Psychiatry. 2002;181:499-504.

4. Saldanha D, Rathi N, Bal H, Chaudhari B. Incidence and evaluation of factors contributing towards postpartum depression. Med J D Y Patil Univ. 2014;7:309-16.

5. Upadhyay RP. Postpartum depression in India: a systematic review and meta-analysis. Bull World Health Organ. 2017;95:706-717B.

6. Bhuvana LG, Sripada R, Devipriya S, Sanjay BBPR, Rajeswari SK, Ramachandran S. Prevalence of postpartum depression at an Indian Tertiary Care Teaching Hospital. IJPCR. 2016;8(6):616-8.

7. Kruthika K, Udayar SE, Mallapur MD. An epidemiological study of postnatal depression among women availing maternal health services in rural areas of Belagavi, Karnataka, India. Int J Community Med Public Health. 2017;4:759-63.

8. Suguna A, Naveen R, Surekha A. Postnatal depression among women attending a rural maternity hospital in south India. National J Community Med. 2015;6(2)297-301.

9. Nimisha DD, Ritambhara MY, Jaishree G. Study of prevalence and risk factors of postpartum depression. National J Med Res 2012;2(2):194-8.

10. Swapan G, Jugal K, Mala YM, Ramji S, Agarwal R. Postpartum Depression in North Indian Women: Prevalence and Risk Factors. J Obstet Gynecol India. 2013;63(4):223-9.

Cite this article as: Sivapragasam V, Manjappa AA, Patil AB, Kalaimani M. Prevalence and risk factors of postpartum depression at a tertiary care institute. Int J Reprod Contracept Obstet Gynecol 2019;8:2773-80. 